\title{
CÚ RoÍ AND SvyATOGOR: A STUDY IN CHTHONIC \\ GRIGORY BONDARENKO
}

\section{Introduction}

Both Early Irish and Russian mythological traditions demonstrate a particular example of an extraordinary character showing supernatural features as well as the features of a chthonic monster: it is Cú Roí mac Daire on the Irish side, and Svyatogor on the Russian side. We have to be careful before arguing that these two mythological characters reflect one particular archetype of a monstrous chthonic creature (cf. views expressed by Henderson (1899) in Ireland and Putilov (1986) in Russia); on the contrary, one has to consider both heroes as complex and independent entities who appear in the two quite distinct mythologies (Early Irish and Russian). This is especially true in relation to the Russian tradition of bylinas which have been preserved orally until the first published editions of the nineteenth century.

An authentic term for bylina among Russian performers was starina ('ancient story, history', an exact equivalent of OI senchas). Both the Early Irish and Russian mythological traditions as they have survived in the textual forms (notwithstanding the differences of their background) bear clear traces of a Christian world-view which makes it even more difficult to establish certain pre-Christian religious or ritualistic patterns allegedly connected with the characters discussed. Nevertheless, archetypal typological similarities between these two heroes make them look like distorted reflections of an ancient chthonic creature/titan, well known in the basic myth. For example, the Indian myth of the heroic god (deva) Indra who fights the arch-titan (asura) (Namuci or Vṛtrá) was one of the sources for Coomaraswamy's interpretation of 'Sir Gawain and the Green Knight', a mediaeval romance based on 'beheading game' reflected in the early Irish tale Fled Bricrenn (Coomaraswamy 1944: 105-106). ${ }^{1}$ The aim of the present paper is to trace these typological similarities which sometimes will lead us to different characters and plots both in Early Irish and in Russian material.

\section{Cú Roí in his royal, universal and chthonic capacities}

Several features of Cú Roí, reflected in Early Irish literature, make him a rather unique or even transcendent character. His name Cú Roí literally means 'a hound of a field/battlefield' which links him with other hound-like warriors of Irish epic literature such as Cú Chulainn etc. Actually he is the second Cú of importance in the Early Irish epos. OI róe 'a level piece of ground, a plain', hence 'a battlefield' (DIL s.v. 2 róe), so the meaning of the second part of our hero's name might have been inclusive of both spacial and military properties. The second element implies a wide range of activities and journeys on open space and in the battlefield made by Cú Roí. It makes him a character closely similar to Russian Svyatogor whom we meet quite often 'in a clear field' (vo chistom, vo poli) (Putilov 1986: 52). Polye 'field, plain, steppe' is the most suitable place for the heroes of Russian bylinas to meet each other, to exchange heroic feats, to fight their enemies and to fight each other. The topos of the 'field' is common both for Russian

\footnotetext{
${ }^{1}$ On the influence of Fled Bricrenn on Sir Gawain and the Green Knight, see (Jacobs 2000: 54).
} 
and for Irish heroic epics. At the same time 'field' does not constitute a proper locus for Cú Roí and Svyatogor. It is merely an outer space for their adventures.

The meaning of róe discussed before was accepted by Rhys, Meyer, d'Arbois, and Stokes. However T.F. O'Rahilly has argued against this view on the basis of the earlier form Cú Rauï, taking OI gen. of róe 'plain' to be rö̈ (disyllabic). According to O'Rahilly, gen. Rauï< Ravios 'roarer?' (a theonym?) (O'Rahilly 1946: 5-6), that is 'the Hound of the Roarer-god?'. It should be stressed here that the name Cú Roí, as well as Svyatogor, just like any keyword in mythopoeic contexts, has probably undergone multiple etymologisations, each of them corresponding to certain motifs connected with these mythological characters (Toporov 1983: 94).

Cú Roí appears in an Old Irish tale Mesca Ulad ('The Intoxication of the Ulaid') at the walls of Temair Lúachra, the southern royal centre, where he settles a dispute between his two druids. It is rather important that in this tale, as in several other sources, Cú Roí is portrayed as a king of Munster with his residence in Temair Luachra. More specifically, he is portrayed as the king of the Clanna Dedad, a branch of the southern Érainn (Ptolemy's Iverni) (Henry 1995: 179). As the Rees brothers pointed out, Cú Roí 'belongs to Ireland, and yet he is not of it' to the same extent as the province of Munster itself (both archaelogically and historically) (Rees \& Rees 1973: 138). The southern fifth of Ireland (and Western Munster particularly) has its unique features reflected both in the literature and in the historical development of this region. ${ }^{2}$ Cú Roí is sometimes viewed as being a central character in a lost Munster cycle of tales (MacKillop 1998: 107).

The author of Mesca Ulad also calls Cú Roí rí in domain 'the king of the world' (Watson 1983: 20. 1. 452), and in this capacity he has to stay outside the inhabited world and remain hidden in his secret centre (Guénon 1958: 68-69). Cú Roí is also known as the king of the world in the later sources: one Middle Irish poem treats him as a king to whom the world submitted (rí ar domun rodét) (Meyer 1901: 38). It seems plausible to trace origins of this specific OI formula to earlier continental Celtic titles found in Gaulish personal names, as in Gaul. Dumnor(e)ix 'Roi-du-Monde-d'en-bas' ('Roi-desTénèbres') <*dubno-rig-s (Delamarre 2003: 151). The relevant inscription accompanied by a depiction of a warrior (king?) handling a severed human head is found on the firstcentury BC Gaulish coin: it reads DUBNOREIX (Maier 2000: 12-13). This image is even more remarkable if we recall a beheading game in Fled Bricrenn. As for the OI concept of the world, we have OI domun <*dubno- 'dark/low' (Kalygin 2002: 96, 97) (Gaul. dubnos, dumnos 'le monde d'en bas'), OI domun also has the meaning 'earth' in the physical sense (DIL s.v. domun), which implies that the word had an earlier significance. Kalygin's argument that Cú Roí means 'the king of the (lower) world' may be correct (Kalygin 2006: 65). Both our heroes (Cú Roí and Svyatogor) owe much to the element of earth: Cú Roí as rí in domain 'the king of the (lower) world' and Svyatogor, dying overwhelmed by the earth power. Although Svyatogor is never called "king" or "prince" in the Russian bylinas, he often boasts of having a special power over the earth: «Kaк $\sigma b l$ я тяги нашел,/Так я бы всю землю поднял!» ('If I could find some traction, I would lift up the whole earth') (Kalugin 1986: 48). The author of one bylina comments on

\footnotetext{
${ }^{2}$ I shall not discuss in detail this special character of Munster in early Irish literature as an abode of áes síde (Banba on Slíab Mis, Bodb and Nár Túathcháech in Síd Boidb, Áine in Cnoc Áine) and other supernatural heroes (Mug Ruith etc.). It would be enough to say that Western Munster possesses certain supernatural qualities and is often set aside the rest of Ireland.
} 
Svyatogor's words: “Впредки не похваляйтесь/ Всёю землёю владети» ('Do not boast anymore to possess the whole earth") (Hilferding 1949: No 185). Both heroes cannot be sustained by their own land (ultimately by the earth itself) and are found fighting in the outer regions or hiding in their mountainous refuge.

The reason for applying the title of rí in domain lies in Cú Roí's nature, in the fact that he is seen as the most non-Irish character among the Irish heroes of the Ulster Cycle. He is the 'king of the world' who cannot be sustained by this human world. His Eastern journeys to Scythia and to Francia are often mentioned and his warlike expeditions in the outer (Eastern) world is one of his prominent features, shown, for example, in Fled Bricrend ('The Bricriu's Feast'):

... ocus ní rabi Cú Roí hi fus ar a cind ind aidchi sin, ocus rofitir co ticfaitis, ocus foracaib comarle lasin mnái im réir na curad, co tísad don turus, dia n-dechaid sair hi tirib Scithiach, fo bith ní roderg $C u$ Ruí a claideb i n-Érind, o rogab gaisced co n-deochaid bás, ocus nocho dechaid bíad n-Erend inna beólu, cein rombói ina bethaid, o roptar slána a secht m-bliadna, úair ni rothallastar a úaill nach a allud nach a airechas nach a borrfad nách a nert nach a chalmatus i n-Érind (Henderson 1899: 100).

....and that night before their (Ulaid's - G.B.) arrival Cú Roí was not there, but he knew they would come, and he gave advice to his wife regarding the heroes until he would return from the journey when he has gone to the east to the Scythian lands, for $\mathrm{Cu}$ Roí had not reddened his sword in Ireland since he took up arms, until his death, and food of Ireland never passed his lips until he was alive, from the age of full seven years, because there was no room in Ireland for his pride, his fame, his rank, his expansion, his strength, and his bravery.

The Eastern world and Scythia are taken here as the furthest lands from Ireland in which a hero like Cú Roí may perform his feats and 'rule' the world. It is not ony Scythia that is mentioned in the stories of Cú Roí: he is said sometimes to fight both in the land of the Franks and in Spain which form in the dindshenchas parts of the Eastern world (Gwynn 1991: 348, 350). There is an earlier reference to Cú Roí's travels into foreign countries in the eighth-ninth century first recension of Aided Con Roí (ACR I): boí náu humi, asa. slaided Albu 7 innsi mara olchene con. rici in mBith Mór ('There was a boat of copper from which he used to plunder Britain and the isles of the sea as far as the Big World') (Thurneysen 1913: 192). This implies that he was outside Ireland most of the time. Bith Mór 'Big World' refers here to the spacious otherworld overseas rather than to the Continent as such. Cú Roí's constant navigation associates him, like the Fomoire, with the element of water and with piracy.

Cú Roí seems not to spend nights in his fortress at all. He keeps it secure in a special magical way. Cú Roí's fortress had strange qualities specific for the universal ruler's palace. It was the centre of Cú Roí's domain and is described in Fled Bricrend in such terms:

Cipé aird do airdib in domain tra i m-beth Curui, dochanad bricht for a chatraig cach naidchi, co m-bo déinithir bróin mulind, conna fogbaithe a ddorus do grés iar fuinud n-grene (Henderson 1899: 102). 
In whatever quarter of the world Cú Roí should happen to be, every night he used to chant a spell over the fortress, and the fortress [revolved] as swiftly as a mill-stone, and its entrance was never to be found after sunset.

Cú Roí's dwelling functions in this way as a symbolic centre of the world at the intersection of the cardinal points. The fortress has a polar significance: the whole world seems to revolve around it, and around a universal ruler. The revolving castle is a significant feature in later Arthurian romances and in medieval European literature. Prester John as a hidden universal ruler also had a revolving castle. The same kind of revolving dwelling is found in the Russian folk tales of the supernatural old hag, Baba Yaga, residing in the woods: the house revolves on hen's legs and allows visitors only by the hag's permission. In a Hungarian tale, a dragon who rules the land of the dead lives in a copper fortress that turns on a goose-leg (Brown 1966: 358). It seems that the revolving dwelling of Cú Roí is also associated with the abode of the dead, in the context of Fled Bricrenn.

Cú Roí's famous revolving fortress and a well where his soul was kept hidden in a salmon are all located on the slopes of Sliab Mis in Western Munster (Thurneysen 1913: 192). The mounatain has a special significance in Cú Roí's myth. In Amra Con Roí, one of the earliest accounts of Cú Roí, he is called māl Mis 'the prince of Mis' (which is glossed .i. ríg montis 'of the king of the mountain') (Henry 1995: 188; Stokes 1905: 5.14). The promontory fort, associated with $\mathrm{Cu}$ Roí, Cathair Con Roí (modern Caherconree) is situated some $630 \mathrm{~m}$ above the sea level on the western edge of the Slieve Mish mountain-range in Co. Kerry. Ruins of the fort have but a single line of defence. The area defended at Caherconree is scarcely a hectare. The wall, well built of soundstone blocks, has internal terracing and still stands to a height in places of more than two metres. Due to its situation it is difficult to envisage this site in occupation during the winter. It is remarkable that in the literature Cú Roí also does not occupy the fortress for many days and nights of his journeys. B. Raftery comments on Caherconree that one can only wonder as to the function, and indeed the date, of such a spectacular fortress (Raftery 2005: 163, 166). In other words this site poses another enigma of Celtic Ireland intermingling myth and history in a strange fashion.

\section{Svyatogor: his locus, his descent and his chthonic attraction}

As for Svyatogor, his universal character and power restrain the hero from living in and even visiting Holy Rus' to the same extent as Cú Roí is restrained from living in Ireland:

На тых горах высокиих, На той на Святой горы, Был бога́тырь чюдныи, Что ль во весь же мир он дивныи, Во весь же мир был дивныи -

Не ездил он на Святую Русь, Не носила его да мать сыра-земля (Kalugin 1986: 42).

On those high mountains, On that Holy mountain

There was a wonderful bogatyr,

He was marvellous throughout the world, 
He was wonderful throughout the world -

He did not go to Holy Rus',

The damp mother earth did not carry him.

This is the beginning of the bylina on the death of Svyatogor which implies the universal fame of the hero. It was an amazing fact for the scholars of the bylinas, noticed especially by Propp, that Svyatogor does not perform heroic feats together with other bogatyrs in Holy Rus' or on its borders (Propp 1958: 78). However, this fact is explained by the nature of the hero: he is famous 'throughout the world' and performs his feats outside the land of Russia. Just like Cú Roí, he is not sustained by the earth of mortals. In several other bylinas he is clearly depicted as a giant 'taller than a standing wood'. Stories similar to the plot of theSvyatogor story are attested in the Balkans and in Chekhia which suggests that the plot is common to the Slavic regions (Balashov, Novichkova 2001: 40; Hapgood 1915: 261). According to Balashov the Holy Mountains of Svyatogor's cycle can be connected with the Carpathian Mountains and the earliest proto-Slavic habitat in a Celto-Slavic contact zone (Balashov, Novichkova 2001: 40). Nor does Toporov (1983: 123-124) rule out the Carpathian proto-Slavic locus for Svyatogor.

Svyatogor is alien to Holy Rus' of the bylinas. His fame is known throughout the world, he is a universal hero if not a universal ruler. His locus is a mountainous region outside Holy Rus', a region of Holy Mountains (Svyatyje gory, Svetye gory). This locus is suggested already by the hero's name Svyatogor, which might have replaced an earlier form (Vostrogor, Vertogor?) in the process of later popular etymologisation (Ivanov, Toporov 1992: 421; Hapgood 1915: 261). On the other hand, mountains are found elsewhere in folklore and myths as a suitable home for giants, ogres and similar creatures. The Holy Mountains (Svyatye gory) do not belong to Holy Rus' of bylinas and Svyatogor often underlines his external position implying that he is not one of the Russian bogatyrs: 'Russian gnats sting painfully' (russkie komary bol'no kusayut); 'I brought a Russian bogatyr (Ilya - G.B.) as a guest' (ya privez russkogo bogatyrya v gosti) etc (Byliny 2003: 125). Holy Mountains (apparently associated with Christian holy places in Palestine) constitute Svyatogor's locus in the same way as the mountain Sliab Mis in the southern extremity of Ireland is Cú Roí's locus in Fled Bricrenn and in Aided Con Roí (Henderson 1899: 100; Thurneysen 1913: 192). It is only the outer mountains that can sustain titanic and superhuman nature of both mythological characters. ${ }^{3}$

Another Svyatogor locus in the epic literature is a mountainous ravine. It is assumed in the bylinas that Svyatogor and the older bogatyrs travel only in the ravines (ездяm нонь они как по шиелейкам) (Byliny 2003: 311). He later rides around the ravines with Ilya of Murom. The ravine combines the functionality of the mountain with the lower world; it is a lower world within the mountain.

Svyatogor's father (sometimes called Gorynya 'Mountainous?') who lives on the Holy Mountains also has specific features of a chthonic monstrous creature. When Svyatogor brings Ilya of Murom to his mountainous home he introduces Ilya to his elderly parent, who is blind but immensely strong. Svyatogor's father is called "old and blind (dark)" (древныли да темныл) (Kalugin 1986: 44), where blindness is a marker of a chthonic

\footnotetext{
${ }^{3}$ On the other hand, one can interpret both Svyatogor's and Cú Roí's locus as a variant of the 'Holy Mountain', which is located in the centre of the world and is implicitly connected with the residence of the universal ruler (such as the King of the World) (Eliade 1968: 310).
} 
nature. Svyatogor warns Ilya not to give his hand to the old giant and Ilya gives him a club (or a bar of a red-hot iron) which is squeezed to foam (Byliny 2003: 125). Svyatogor's father unlike his son lives permanently on the mountain and functions as the most ancient and long-living character in the bylinas (he even outlives his own son). Svyatogor himself is described in this fragment as blind and deaf in Holy Rus' which is foreign and alien to him (when his father asks him what did he see or hear in Holy Rus' Svyatogor replies: " $Я$ что не видел, что не сльшиал, а только привез богатыря со святой Руси» 'I have not seen anything, I have not heard anything, I have just brought a bogatyr from Holy Rus'). Toporov suggests that Svyatogor as a creature from the land of the dead cannot see and hear anything in the land of the living (Toporov 1983: 94). Otherwise the passage can be interpreted as an intrusion of the chthonic character into the land of mortals where he cannot perceive any details such as the features of the landscape, elements of human behaviour or the bogatyrs' thrusts.

The bylinas contain two stories of Svyatogor's death. In both Svyatogor's cycle and Cú Roí's the death of a hero has a central position. One bylina tells that he died overwhelmed by the telluric power contained in a tiny bag given to him by the peasant Mikula or which he found in the steppe/field. Svyatogor boasts that he can turn the whole earth with a special power/traction (тяга) but when he finds it in the bag he seems not to be able to lift it up. The giant is attracted by the chthonic abyss and absorbs himself in the element of earth:

Ухватил он сумочку обема рукама,

Поднял сумочку повыше колен:

И по колена Святогор в землю угряз,

А по белу лицу не слезы,

А кровь течет.

Где Святогор увяз,

Тут и встать не мог,

Тут ему было и кончание (Kalugin 1986: 48).

He caught the tiny bag with both his hands,

He lifted the tiny bag above his knees:

And Svyatogor was bogged down in earth up to his knees,

And it was not tears

But blood flows on his white face.

On the spot where Svyatogor was bogged down

There he could not stand up,

There was his end.

Another variant of Svyatogor's death relates how together with Ilya of Murom he finds a gigantic coffin up in the mountains. The coffin fits only Svyatogor. The same chthonic attraction makes Svyatogor lie in the coffin without any return (Kalugin 1986: 50). According to another variant of the story, recorded by K. Aksakov, Svyatogor always lies on the mountain and addresses Ilya: «Видишь, какой я урод; меня и земля не держит, нашел себе гору и лежу на ней» ('Look what kind of a monster I am; the earth does not hold me, I found a mountain for myself and I am lying here') (Kalugin 1986: 49). It is only a mountain that can offer the giant escape from submerging into the earth. One can compare this creature with another monster from Indian myth, a hideous 
snake-like Vṛtrá lying on the mountain and later killed by Indra (RgVeda, I, 32, 1-2). Both the landscape features of the plot and Svyatogor's/Vrtrá's deadly and passive qualities correspond to the same basic myth (Toporov 1983: 106). As Ivanov and Toporov have suggested, the original form of Svyatogor's name was similar to Vostrogor (a mythic bird), Vertogor and veretnik (a bird-like and snake-like creature) (Ivanov, Toporov 1992: 421) which connects Svyatogor with Vrtrá rather than with an Iranian god Veretragna or Vedic Vrtráhan 'Vrtrá's killer, Indra', as Toporov has suggested previously. It is also significant that in the bylinas of the Pudozh region Svyatogor is called Gorynich (Горынич 'the son of Gorynya') in the same manner as the famous Russian dragon Zmey Gorynych ('He-snake, son of Gorynya') while the name Gorynya derives from Russian zopa 'mounatin' (Parilova, Soymonov, Astakhova 1941: No 40). According to other bylinas, Goryn' (Горынь) is a huge snake and an enemy of the bogatyrs (Selivanov 1988: 367).

\section{A possible biblical influence}

The earth cannot hold such 'titans' as Svyatogor and Cú Roí; it swallows Svyatogor when he is confronted with its great weight. He goes back to the element of earth, he submerges into earth, willingly or unwillingly. The death of Cú Roí is also the most important element in his cycle. The death of giants (or titans) is, of course, a well-known topos in many traditions including the Biblical tradition. It marks the end of a primordial epoch and the beginning of the domination of humans. That is why both tragic giants are doomed from the beginning of their stories (cp. a phrase by Vertogor the giant-titan from a Russian tale: "Рад бы принять тебя, Иван-царевич, да мне самому жить немного. Видишь, поставлен я горы ворочать; как справлюсь с этими последними -- тут и смерть моя" ("I would eagerly meet you, O Ivan the prince, but I will not survive long enough. See, I am left here to move the mounatins; when I finish with them, there will be my death') (Afanasiev 1936: No 93; Propp 1958: 76). The earliest reference to Cú Roí in a difficult Cín Dromma Snechta text Forfess Fer Fālgae mentions Cú Roí's 'gory grave' (crolecht Caunrai) (Meyer 1912: 565). It is significant that both characters are implicitly compared with the most titanic of the Old Testament heroes, Samson, whose death was inflicted by his unfaithful mistress, Delilah. Svyatogor is literally called Samson in several bylinas; other bylinas mention another 'elder' bogatyr called Samson along with Svyatogor (Propp 1958: 566-567). Cú Roí in his turn is betrayed by his wife Bláthnait in both variants of Aided Con Roí: she bound his long hair to the shafts and pillars (dona cholbaib 7 dona tuireadhaib) in his fortress (Best 1905: 24). The episode is clearly a contamination of two fragments from the Book of Judges. In the first of them, Delilah wove Samson's hair and then had it cut off (Judges, 16, 19), and in the second, Samson destroys the pillars of the Philistines' house (Judges, 16, 29). Like Samson, Cú Roí throws stones at his enemies from his fort, 'throwing stones' being a well-known motif in many legends about giants.

\section{A chthonic creature and its friend/enemy}

Both Cú Roí and Svyatogor have a typologically similar friend/enemy from the ranks of mortal heroes. Cú Chulainn plays this role for Cú Roí, Ilya of Murom for Svyatogor. Their relations deserve a special study but I would like to stress here certain characteristics relevant for our subject. Firstly, it is made clear in the sources that both Cú 
Roí and Svyatogor are invincible adversaries for otherwise omnipotent heroes such as Cú Chulainn and Ilya. Ilya was advised by the healers-pilgrims (калики) not to fight with Svyatogor and other 'elder' bogatyrs including Samson: не выходи драться с Святогором-богатырем: его и земля на себе через силу носит; не ходи драться с Самсоном-богатырем: у него на голове семь власов ангельских ('do not come out to fight with Svyatogor, the bogatyr: even the earth carries him with great effort; do not come out to fight with Samson, the bogatyr: he has seven angelic hairs on his head') (Kalugin 1986: 37). Note here the near equivalence of the Russian bogatyr, Svyatogor, and the Old Testament hero, Samson.

Cú Roí is the only hero opposing the Ulaid who does not fight with Cú Chulainn in Táin Bó Cuailnge. It was against his honour to kill a weaker enemy, especially since Cú Chulainn was seriously wounded: Ní ba fearrda la Coin Ruí mac Dáiri teacht íarom ara cheand ind fir tregdaithi créchtaigthi, ar ro bíth Cú Chulaind co ndec[h]aid a áltaib dó ('Cú Roí, son of Dáire, thought it did not befit a man to attack one stabbed and wounded, for Cú Chulainn had been wounded and went with his wounds to him') (O'Rahilly 1976: 103, 1l. 3398-3400). It was Cú Roí who assigned a champion's portion to Cú Chulainn in Fled Bricrenn acting as a supreme and independent judge. On the other hand, Cú Roí was the only one who could humiliate Cú Chulainn, showing his superhuman telluric power. In Aided ConRoí I when Cú Chulainn tries to stop him from driving off the cows, Cú Roí rams him into the ground up to his armpits: fa.cairt úad isin talmain, aill co a glún, a fecht n-aill co a thóin, a fecht n-aill co a cris, a n-aill co [a] dí oxail ('He (Cú Roí) threw him (Cú Chulainn) into the ground, first time up to his knee, next time up to his rump, next time up to his belt, and next time up to his armpits') (Thurneysen 1913: 192; Best 1905: 33). (Compare this image with Svyatogor gradually submerging into the ground in one of the bylinas: both characters express their telluric connection in different ways.)

In the same manner Svyatogor humiliates Ilya: he puts him in his pocket immersing him into his chthonic element (Да засунул где ёго да во глубок корман 'Не put him in his deep pocket' (Byliny 2003: 119), where корман 'pocket' is clearly a later modernisation of the motif). It is significant that both chthonic creatures spare heroes' lives; it was important for them to show their power and dignity. As it appears impossible for the heroes to fight the giants in single combat, the only way to defeat them is by trickery. Svyatogor and Ilya at a certain stage have become sworn brothers (Kalugin 1986: 33), but it only postpones Svyatogor's tragic death in a coffin. Even while dying in the tomb Svyatogor tries to destroy Ilya with his last breath as a pretext to giving him his superhuman power. Ilya carefully escapes death in different ways according to different bylinas (Kalugin 1986: 34, 41). As E.A. Gray has pointed out, the same rules of behaviour apply to pair of the hero-god and the titan found in Indian culture: Indra and Namuci. The latter is the 'natural enemy' of the gods and an invincible enemy: he can only be slain by magical means. A pact of friendship between the two provides a context in which Indra can defeat Namuci by trickery (Gray 2005: 79-80). ${ }^{4}$ As with Cú Chulainn facing Cú Roí and Ilya facing Svyatogor, only an act of treachery can guarantee success. Cú Chulainn beheads the giant with his wife's help, and Ilya entices Svyatogor to lie down in the coffin. In both cases the conflict is between the most prominent hero and the ancient chthonic creature endowed with a touch of generosity.

\footnotetext{
${ }^{4}$ Another monster killed by Indra is a hideous snake-like Vṛtrá lying on the mountain
} 


\section{Conclusion}

Cú Roí and Svyatogor, the two mythological characters discussed, play essentially the same rôle of chthonic monsters in the basic myth. They act as an 'obstacle', 'barrier' for human heroes such as Ilya and Cú Chulainn. They are primeval characters in both traditions, that is why they are not associated with the dominant population groups: Svyatogor is not of Rus' but from outer space (mounatins on the borderland, Carpathians?), Cú Roí is from outer Munster, from marginal auto-chthonous (sic!) population groups. At the same time both characters as they have survived in the literature are contaminated by Biblical and apocryphal stories of Samson and Delilah. This is how they became incorporated into a comparatively new synthetic literary tradition.

\section{BIBLIOGRAPHY}

Afanasiev, A.N., ed., 1936-1940, Народные русские сказки [Russian folk tales], т. I-III. Ленинград: Academia, Гослитиздат.

Balashov, D. M., Novichkova, T. A., 2001, Русский былинный эпос ['The Russian Epos of the Bylinas'], Былины: в 25 т. Т. 1. Былины Печоры: Север Европейской России [Bylinas. Vol. I. Bylinas of the Pechora: North European Russia]. СПб: Наука; М.: Классика, 21-78.

Best, R. I., ed., 1905, 'The tragic death of Cúrói mac Dári', Ériu, 2, 18-35.

Brown, A. C. L., 1966, The Origin of the Grail Legend. New York: Russell \& Russell.

Byliny, 2003, Былины: в 25 т. Т. 3: Былины Мезени: Север Европейской России [Bylinas. Vol. 3. Bylinas of the Mezen: North European Russia]. СПб: Наука.

Coomaraswamy, A., 1944, 'Sir Gawain and the Green Knight: Indra and Namuci', Speculum, XIX, 104-125.

Delamarre, X., 2003, Dictionnaire de la langue gauloise. Paris: Errance.

Eliade, M., 1968, Traité d'histoire des religions. Paris: Payot.

Gray, E. A., 2005, 'The Warrior, the Poet and the King: 'The Three Sins of the Warrior' and the Death of Cú Roí', in: J. F. Nagy \& L. E. Jones, eds., Heroic Poets and Poetic Heroes in Celtic Tradition. A Festschrift to Patrick K. Ford (CSANA Yearbook 3-4), Dublin: Four Courts Press, 74-90.

Guénon, R. 1958, Le roi du monde. Paris: Gallimard.

Gwynn, E., ed., 1991, The Metrical Dindshenchas, Part IV, Dublin: DIAS.

Hapgood, I. F., 1915, The Epic Songs of Russia. London: Constable.

Henderson, G., ed., 1899, Fled Bricrend. London: Irish Texts Society.

Henry, P.-L., 1995, 'Amra Con Roi (ACR): Discussion, edition, translation', ÉC, 31, 179194.

Hilferding, A.F., ed., 1949, Онежские былины, записанные летом 1871 года [Bylinas from the Onego lake collected in summer 1871]. Т. II. М.; Л.: Издательство АН СССР.

Ivanov, V.V., Toporov, V.N., 1992, Святогор ['Svyatogor'], in: Мифы народов мира. [Myths of the world] T. 2. М.: Советская энциклопедия.

Jacobs, N., 2000, 'Fled Bricrenn and Sir Gawain and the Green Knight', in: P. Ó Riain, ed., Fled Bricrenn: Reassessmentsby. Dublin: Irish Texts Society, 40-55.

Kalugin, V.I., ed., 1986, Былины [Bylinas]. М.: Современник. 
Kalygin, V. P., 2002, Кельтская космология ['Celtic cosmology'], in: Представления о смерти и локализация иного мира у древних кельтов и германцев, отв. ред. Т.А. Михайлова [T. A. Mikhaylova, ed., Ideas of Death and Location of the Otherworld in Early Celtic and Germanic Traditions]. М.: Языки славянской культуры, 82-129.

Kalygin, V.P., 2006, Этимологический словарь кельтских теонимов [Etymological Dictionary of Celtic Theonyms]. М.: Наука.

MacKillop, J., 1998, Dictionary of Celtic Mythology, Oxford: Oxford Universty Press.

Maier, B., 2000, 'Comparing Fled Bricrenn with Classical Descriptions of Continental Celts: Parallels, Problems and Pitfalls', in: P. Ó Riain, ed., Fled Bricrenn: Reassessments, Dublin: Irish Texts Society, 1-14.

Mazon, A., 1932, 'Svjatogor ou Saint-Mont le géant', Revue des études slaves, XII, fasc. 1-2, 160-201.

Meyer, K. 1901, 'Mitteilungen aus irischen handschriften. Gedicht auf Cúrói Mac Dári', ZCP, 3, 37-39.

Meyer, K. 1912, 'Mitteilungen aus irischen handschriften. Forfess Fer Fālgae', ZCP, 8, 564-565.

O'Rahilly, T., 1946, Early Irish History and Mythology, Dublin: DIAS.

O'Rahilly, C., ed., 1976, Táin Bó Cúalnge. Recension 1. Dublin: DIAS.

Parilova, G.N., Soymonov A.D., Astakhova A.M., ed., 1941, Былины Пудожского края [Bylinas of the Pudozh region]. Петрозаводск: Государственное издательство КФССР.

Propp, V.Ya., 1958, Русский героический эпос [The Russian Heroic Epos]. М.: Государственное издательство художественной литературы.

Putilov, B.N., ed., 1986, Былины: Сборник. Вступ. ст., сост., подгот. текстов и примеч. Б. Н. Путилова [Bylinas: Collection, ed. by B. N. Putilov]. Л.: Советский писатель.

Raftery, B., 2005, 'Iron-age Ireland', in: D. Ó Cróinín, ed., A New History of Ireland. Vol.I, Oxford: Oxford University Press, 134-181.

Rees, A. \& B., 1973, Celtic Heritage. London: Thames and Hudson.

Selivanov, F.M., ed., 1988, Былины [Bylinas], М.: Советская Россия.

Stokes, W., ed., 1905, 'The eulogy of Cú Rói', Ériu, 2, 1-14.

Thurneysen, R., ed., 1913, 'Die Sage von CuRoi', in ZCP, 9, 189-234.

Toporov, V.N., 1983, 'Русск. Святогор: свое и чужое (к проблеме культурноязыковых контактов)' ['Russian Svyatogor: native and foreign (on the problem of cultural and linguistic contacts)'], Славянское и балканское языкознание. Проблемы языковых контактов [Slavic and Balkan linguistics. Linguistic contacts' issues]. Москва: Наука, 89-125.

Watson, J. Carmichael, ed., 1983, Mesca Ulad. Dublin: DIAS. 